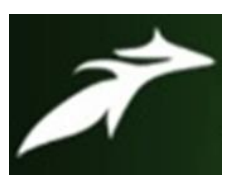

Kamishetty Uday Kumar et al, International Journal of Advances in Agricultural Science \& Technology, Vol.8 Issue.10, October-2021, pg. 29-38

\title{
Knowledge of Farmers on Improved Cotton Production Practices in Yadadri Bhuvanagiri District of Telangana
}

\author{
Kamishetty Uday Kumar ${ }^{1}$; Dipak Kumar Bose ${ }^{2}$; Jahanara ${ }^{3}$ \\ Research Scholar ${ }^{1}$, Associate Professor ${ }^{2}$, Professor and $\mathrm{Head}^{3}$ \\ Department of Agricultural Extension and Communication, SHUATS, Prayagraj, Uttar Pradesh, India
}

DOI: 10.47856/ijaast.2021.v08i10.004

\begin{abstract}
India is the pioneer country for the commercial cultivation of cotton. Cotton is one of the principal commercial crops and has been one of the main sources of India's economic growth and foreign exchange earner. It is popularly known as 'White Gold'. In india it is important cash and commercial crop valued for its fiber and vegetable oil. The study was conducted in Ramannapet block of Yadadri Bhuvanagiri District was selected purposively based on the maximum cotton grower and 120 respondents were selected randomly from six villages of the ramannapet block. The data was collected with the help of structured schedule analyzed statistically. The study revealed that majority of respondents had medium level of socioeconomic status and knowledge on recommended improved production practices of cotton. To access the knowledge of the respondents about improved cotton production practices.
\end{abstract}

Keywords: Improved practices of cotton, cotton growers, Knowledge and Association.

\section{Introduction:}

Cotton is one of the most important fiber and cash crop of India and plays a dominant role in the industrial and agricultural economy of the country. Cotton is the most important fiber crop not only of India but of the entire world. It provides the basic raw material (cotton fiber) to cotton textile industry. Cotton in India provides direct livelihood to 6 million farmers and about 40 -50 million people are employed in cotton trade and its processing. India has the largest area under cotton cultivation in the world though it is the world's third largest producer of cotton after China and the USA. Currently it is grown over 6 per cent of the net sown area. It plays a 


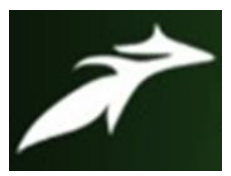

Kamishetty Uday Kumar et al, International Journal of Advances in Agricultural Science \& Technology, Vol.8 Issue.10, October-2021, pg. 29-38

ISSN: 2348-1358 Impact Factor: 6.057

NAAS Rating: 3.77

prominent role in the national and international economy due to its high commercial value, it is also popularly known as 'White Gold'. In India, it is important cash and commercial crop valued for its fiber and vegetable oil. It is a source for earning the valuable foreign exchange by providing employment to millions of people and hence plays a significant role in the national economy. The diverse products obtained from cotton include textile raw material, cottonseed is a major source of vegetable oil and cotton cake as a rich source of high quality protein for livestock feed. Cotton is primarily grown as a fiber crop. It is harvested as 'seed cotton', which is then 'ginned' to separate the seed and lint (Kalidasan 2020).

India is one of the largest producers of cotton in the world accounting for about $23 \%$ of the world cotton production. The yield per $\mathrm{kgs}$ hectare which is presently $466 \mathrm{~kg} / \mathrm{ha}$ is still lower against the world average yield of about $762 \mathrm{Kg} / \mathrm{ha}$ (Cotton Corporation of India 2014).

Presently, most of the country's cotton production comes from eleven major cotton growing States, which can be grouped into three regions viz., Northern Zone comprising Punjab, Haryana and Rajasthan, Central zone comprising of Gujarat, Maharashtra, Madhya Pradesh and Orissa and Southern Zone comprising of Andhra Pradesh, Telangana, Karnataka and Tamilnadu. It directly or indirectly provides huge employment in rural as well as urban sectors. It provides a livelihood to more than 5.80 million cotton farmers and 40-50 million people engaged in related activities in India by way of support in agriculture, processing, and use of cotton in textiles.

\section{Research Methodology}

This section describes the approaches and methods employed for data collection and analysis. Telangana state was selected purposively because more public-private sectors are working for Upliftment of the Socio-economic condition of the rural families. The Yadadri Bhuvanagiri District was selected purposively for research investigation because it is one of the largest districts in Telangana. There are total 17 blocks in Yadadri Bhuvanagiri district of Telangana, out of which Ramannapet block have been selected purposively on the 


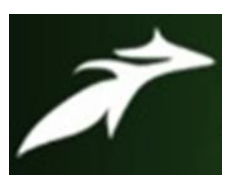

Kamishetty Uday Kumar et al, International Journal of Advances in Agricultural Science \& Technology, Vol.8 Issue.10, October-2021, pg. 29-38

ISSN: $2348-1358$ Impact Factor: 6.057

NAAS Rating: 3.77

basis of maximum area under cotton cultivation. A complete list of all the villages were major farmers involved with cotton cultivation practices with the personnel of revenue and agriculture department from the identified block. Six villages were selected on the basis of maximum farmers involved in cotton cultivation one hundred and twenty respondents were selected randomly with the help of village Sarpanch and agriculture supervisor of respective village. The Primary data was collected with the help of personal interview technique with the help of interview schedule with especially objectives, focused study. Secondary data was collected from library, journals, books, papers, and other materials related to study. Quantitative data collected from the household survey were analyzed using descriptive statistical methods. The responses to the raw quantitative data were coded and stored using Microsoft Excel spreadsheet in order to avoid respondent anonymity. They were summarized while qualitative responses were tallied and finally prioritized in order to determine trends and patterns in the data and draw logical conclusions.

\section{Results and Discussion}

Table-1: Socio-economic profile of the respondents.

\begin{tabular}{|c|c|c|c|c|}
\hline Sl.no. & \multicolumn{2}{|c|}{$\begin{array}{l}\text { Socio-economic profile of the } \\
\text { respondents }\end{array}$} & Frequency & Percentage \\
\hline \multirow[t]{3}{*}{1.} & \multirow[t]{3}{*}{ Age } & Young (20-35years) & 30 & 25.00 \\
\hline & & Middle (36-55years) & 58 & 48.33 \\
\hline & & Old (above55years) & 32 & 26.67 \\
\hline \multirow[t]{4}{*}{2.} & \multirow[t]{4}{*}{ Education } & Illiterate & 21 & 17.50 \\
\hline & & Primary & 22 & 18.33 \\
\hline & & high school & 37 & 30.83 \\
\hline & & College & 40 & 33.34 \\
\hline \multirow[t]{3}{*}{3.} & \multirow[t]{3}{*}{ Annual Income } & Low(uptoRs.80,000) & 42 & 35.00 \\
\hline & & Medium(Rs.80,000-1,20,000) & 55 & 45.83 \\
\hline & & High(AboveRs.1,20,000) & 23 & 19.17 \\
\hline \multirow[t]{3}{*}{4.} & \multirow{3}{*}{$\begin{array}{l}\text { Land } \\
\text { holding }\end{array}$} & Low(up to 1ha) & 29 & 24.17 \\
\hline & & Medium(1-2ha) & 69 & 57.50 \\
\hline & & High(Above 2ha) & 22 & 18.33 \\
\hline
\end{tabular}




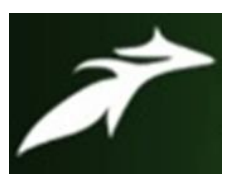

Kamishetty Uday Kumar et al, International Journal of Advances in Agricultural Science \& Technology, Vol.8 Issue.10, October-2021, pg. 29-38

ISSN: 2348-1358 Impact Factor: 6.057

NAAS Rating: 3.77

\begin{tabular}{|c|c|c|c|c|}
\hline \multirow[t]{3}{*}{5.} & \multirow{3}{*}{$\begin{array}{l}\text { Mass Media } \\
\text { Exposure }\end{array}$} & Low(4-7) & 68 & 56.67 \\
\hline & & Medium(8-10) & 49 & 40.83 \\
\hline & & High(11 above) & 03 & 2.50 \\
\hline \multirow[t]{3}{*}{6.} & \multirow{3}{*}{$\begin{array}{c}\text { Extension } \\
\text { Contacts }\end{array}$} & Low (5-7) & 85 & 70.83 \\
\hline & & Medium(8-9) & 29 & 24.17 \\
\hline & & High(10 above) & 06 & 5.00 \\
\hline \multirow[t]{3}{*}{7.} & \multirow{3}{*}{$\begin{array}{l}\text { Sources of } \\
\text { information }\end{array}$} & Low (11-16) & 14 & 11.67 \\
\hline & & Medium (17-21) & 88 & 73.33 \\
\hline & & High (10 above) & 18 & 15.00 \\
\hline \multirow[t]{3}{*}{8.} & \multirow[t]{3}{*}{ Innovativeness } & Low(6-8) & 54 & 45.00 \\
\hline & & Medium(9-10) & 63 & 52.50 \\
\hline & & High(11 above) & 03 & 2.50 \\
\hline \multirow[t]{3}{*}{9.} & \multirow[t]{3}{*}{ Progressiveness } & Low(6-8) & 92 & 76.67 \\
\hline & & Medium(9-10) & 26 & 21.67 \\
\hline & & High(11 above) & 02 & 1.66 \\
\hline \multirow[t]{3}{*}{10.} & \multirow{3}{*}{$\begin{array}{c}\text { Risk } \\
\text { Orientation }\end{array}$} & Low(6-8) & 15 & 12.50 \\
\hline & & Medium(9-10) & 59 & 49.17 \\
\hline & & High(11 above) & 46 & 38.33 \\
\hline
\end{tabular}

The above table shown that majority of respondents belonged to Middle age group. This group alone constitutes 48.33 per cent of the total sample. A considerable number of respondents 25 per cent were front the young age group and 26.67 per cent respondents were found to be from High age group.

Majority of respondents belonged to 35.83 per cent growers were illiterate and primary followed by 30.83 per cent cotton growers were High school and 33.34 per cent were College. Finally the results clearly indicates that majority of the respondents belongs to illiterate and Primary.

Majority of respondents belonged to the medium level above 80,000-1, 20,000 Annual Income. This group alone constitutes 45.83 per cent of the total sample. A considerable number of respondents 35 per cent were from the up to 80,000 income and 19.17 per cent respondents were found to be from as above 1,20,000 of annual income. Majority of respondents have 57.50 per cent farmers possessed medium amount of land holding (1-2 hac), whereas 24.17 per cent 


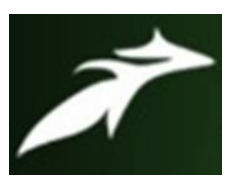

Kamishetty Uday Kumar et al, International Journal of Advances in Agricultural Science \& Technology, Vol.8 Issue.10, October-2021, pg. 29-38

ISSN: 2348-1358 Impact Factor: 6.057

NAAS Rating: 3.77

farmers having low amount of land holding (up to1 hac) and 18.33 per cent of farmers are having high amount of land holding (above 2 hac)

Majority of farmers belonged to the low level of mass media exposure. This group alone constitutes 56.67 per cent of the total sample. A considerable number of respondents 40.83 per cent were from medium level of mass media exposure and 2.50 per cent respondents were found to be high level of mass media exposure.

Majority of respondents belonged to the low level of Extension Contact. This group alone constitutes 70.83 per cent of the total sample. A considerable number of respondents 24.17 per cent were from medium level of Extension Contact and 5 per cent respondents were found to be high level of extension contact.

Majority of respondents belonged to the 11.67 per cent were low level source of information, followed by 73.33 per cent had medium level of source of information and 15.00 per cent is high level of source of information.

Majority of respondents 45.00 per cent low in innovativeness, followed by 52.50 per cent had medium and 2.50 per cent cotton growers had high participation in innovativeness.

Majority of respondents 76.67 per cent of low progressiveness followed by 21.67 per cent of medium progressiveness and 1.66 per cent of high progressiveness.

Most of the respondents belonged to the medium level of risk orientation capacity. This group alone constitutes 49.17 per cent of the total sample. A considerable number of respondents 38.33 per cent were from high level of risk orientation capacity and 12.5 percent respondents were found to be low level of risk orientation capacity Rajeshwar et al (2019) and Jeya (2020). 


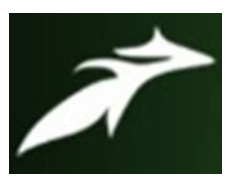

Kamishetty Uday Kumar et al, International Journal of Advances in Agricultural Science \& Technology, Vol.8 Issue.10, October-2021, pg. 29-38

ISSN: 2348-1358 Impact Factor: 6.057

NAAS Rating: 3.77

Table 2: Knowledge of the respondents towards improved production practices of cotton.

\begin{tabular}{|c|c|c|c|c|}
\hline \multirow{2}{*}{$\begin{array}{l}\text { SL. } \\
\text { NO. }\end{array}$} & \multirow{2}{*}{ STATEMENT } & \multicolumn{3}{|c|}{ RESPONSE } \\
\hline & & $\begin{array}{l}\text { Fully } \\
\text { correct } \\
\text { F (P) }\end{array}$ & $\begin{array}{l}\text { Partially } \\
\text { correct } \\
\text { F }(\mathbf{P})\end{array}$ & $\begin{array}{c}\text { Not } \\
\text { Correct } \\
\text { F (P) }\end{array}$ \\
\hline 1. & $\begin{array}{l}\text { Field preparation: } \\
\text { I Traditional method- 2-3 times ploughing } \\
\text { II Surface seeding method }\end{array}$ & $\begin{array}{c}98 \\
(81.67)\end{array}$ & $\begin{array}{c}15 \\
(12.50)\end{array}$ & $\begin{array}{c}07 \\
(5.83)\end{array}$ \\
\hline 2. & $\begin{array}{l}\text { Improved variety: } \\
\text { I. Bhakti } \\
\text { II.Jagadamba } \\
\text { III. Mallika } \\
\text { IV. Jadoo }\end{array}$ & $\begin{array}{c}108 \\
(90.00)\end{array}$ & $\begin{array}{c}10 \\
(08.33)\end{array}$ & $\begin{array}{c}02 \\
(1.67)\end{array}$ \\
\hline 3. & \begin{tabular}{cc}
\multicolumn{2}{c}{ Seed and its treatment: } \\
I. & Carbendazim \\
II. & Azospirillum
\end{tabular} & $\begin{array}{c}70 \\
(58.33)\end{array}$ & $\begin{array}{c}32 \\
(26.67)\end{array}$ & $\begin{array}{c}18 \\
(15)\end{array}$ \\
\hline 4. & $\begin{array}{l}\text { Sowing time: } \\
\text { June - July }\end{array}$ & $\begin{array}{c}116 \\
(96.67)\end{array}$ & $\begin{array}{c}01 \\
(0.83)\end{array}$ & $\begin{array}{c}03 \\
(02.50)\end{array}$ \\
\hline 5. & $\begin{array}{l}\text { Spacing: } \\
60 \times 75 \mathrm{~cm}\end{array}$ & $\begin{array}{c}89 \\
(74.17)\end{array}$ & $\begin{array}{c}27 \\
(22.50)\end{array}$ & $\begin{array}{c}04 \\
(03.33)\end{array}$ \\
\hline 6. & $\begin{array}{l}\text { Fertilizers: } \\
\text { 100:50:50 Kg NPK/ha }\end{array}$ & $\begin{array}{c}41 \\
(34.17) \\
\end{array}$ & $\begin{array}{c}77 \\
(64.17) \\
\end{array}$ & $\begin{array}{c}02 \\
(01.66) \\
\end{array}$ \\
\hline 7. & $\begin{array}{l}\text { Irrigation: } \\
\text { 2times }\end{array}$ & $\begin{array}{c}19 \\
(15.84)\end{array}$ & $\begin{array}{c}94 \\
(78.33)\end{array}$ & $\begin{array}{c}07 \\
(5.83)\end{array}$ \\
\hline 8. & Weeding and hoeing operations: & $\begin{array}{c}20 \\
(16.67) \\
\end{array}$ & $\begin{array}{c}98 \\
(81.67) \\
\end{array}$ & $\begin{array}{c}02 \\
(01.66) \\
\end{array}$ \\
\hline 9. & \begin{tabular}{ll}
\multicolumn{2}{l}{ Weed control: } \\
I. & Hand weeding \\
II. & Herbicides
\end{tabular} & $\begin{array}{c}79 \\
(65.83)\end{array}$ & $\begin{array}{c}32 \\
(26.67)\end{array}$ & $\begin{array}{c}09 \\
(07.50\end{array}$ \\
\hline 10. & $\begin{aligned} & \text { Diseases: } 1 . \text { Root knot } \\
& \text { 2. Ball rot } \\
& \text { 3. Fusarium wilt }\end{aligned}$ & $\begin{array}{c}42 \\
(35.00)\end{array}$ & $\begin{array}{c}72 \\
(60.00)\end{array}$ & $\begin{array}{c}06 \\
(5.00)\end{array}$ \\
\hline 11. & $\begin{array}{l}\text { Harvesting: } \\
1 \text { 60-180days }\end{array}$ & $\begin{array}{c}69 \\
(57.50)\end{array}$ & $\begin{array}{c}48 \\
(40.00) \\
\end{array}$ & $\begin{array}{c}03 \\
(02.50)\end{array}$ \\
\hline 12. & $\begin{array}{l}\text { Yield : } \\
\text { 1.5-3tonnes/ha }\end{array}$ & $\begin{array}{c}69 \\
(57.50)\end{array}$ & $\begin{array}{c}49 \\
(40.83)\end{array}$ & $\begin{array}{c}02 \\
(01.67)\end{array}$ \\
\hline
\end{tabular}

Fully correct (F.C.), Partially correct (P.C.), Not correct (N.C.) Frequency (F), Percentage (P). 


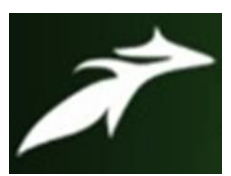

Kamishetty Uday Kumar et al, International Journal of Advances in Agricultural Science \& Technology, Vol.8 Issue.10, October-2021, pg. 29-38

ISSN: 2348-1358 Impact Factor: 6.057

NAAS Rating: 3.77

\section{From the above table major findings were}

$81.67 \%$ of farmer's fully correct recommended field preparation for improved production practices of cotton. $90 \%$ of farmer's fully correct recommended improved variety for improved production practices of cotton. 58.33\% of farmer's fully correct recommended seed and its treatment for improved production practices of cotton. $96.67 \%$ of farmer's fully correct recommended sowing time for improved production practices of cotton.74.17\% of farmer's fully correct recommended spacing for improved production practices of cotton.64.17\% of farmer's partially correct recommended fertilizers for improved production practices of cotton.78.33\% of farmer's partially correct recommended irrigation for improved production practices of cotton. $81.67 \%$ of farmer's partially correct recommended weeding and hoeing operations for improved production practices of cotton. $65.83 \%$ of farmer's fully correct recommended weed control for improved production practices of cotton. $60 \%$ of farmer's partially correct recommended diseases for improved production practices of cotton. $57.50 \%$ of farmer's fully correct recommended harvesting for improved production practices of cotton. $57.50 \%$ of farmer's fully correct recommended yield for improved production practices of cotton. This findings are lines with Patel and Sanwal (2015).

Table 3: Overall knowledge level of the respondents towards improved cotton production practices.

\begin{tabular}{|c|c|c|c|}
\hline Sl.no & Categories & Frequency & Percentage \\
\hline 1 & Low (24-27) & 25 & 20.83 \\
\hline 2 & Medium (28-30) & 55 & 45.83 \\
\hline 3 & High (31 Above ) & 40 & 33.34 \\
\hline & TOTAL & 120 & 100.00 \\
\hline
\end{tabular}




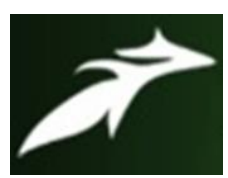

Kamishetty Uday Kumar et al, International Journal of Advances in Agricultural Science \& Technology, Vol.8 Issue.10, October-2021, pg. 29-38

ISSN: 2348-1358 Impact Factor: 6.057

NAAS Rating: 3.77

The table 3 shows that majority of respondents $45.83 \%$ belonged to the medium level of knowledge group. A considerable number of respondents $33.34 \%$ were belonged to the high level of knowledge group and $20.83 \%$ respondents were belonged to the low level of knowledge group. These findings are lines with Jeya (2020).

Table 4: Association between independent variables and knowledge of the respondents towards improved cotton production practices.

\begin{tabular}{|c|c|c|}
\hline Sl. no. & Characteristics & $\begin{array}{c}\text { Coefficient of correlation 'r' with } \\
\text { knowledge of cotton growers. }\end{array}$ \\
\hline 1. & Age & $0.238^{*}$ \\
\hline 2. & Education & $0.303^{*}$ \\
\hline 3. & Annual income & $0.207^{*}$ \\
\hline 4. & Land holding & $0.260^{*}$ \\
\hline 5. & Mass media exposure & $0.323^{*}$ \\
\hline 6. & Extension contacts & $0.202^{*}$ \\
\hline 7. & Source of information & $0.327^{*}$ \\
\hline 8. & Innovativeness & $0.341^{*}$ \\
\hline 9. & Progressiveness & $0.283^{*}$ \\
\hline 10. & Risk orientation & \\
\hline & &
\end{tabular}

* Significant at $1 \%$ level of probability, ** Significant at $5 \%$ level of probability, NS = Non-Significant 


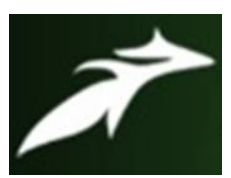

Kamishetty Uday Kumar et al, International Journal of Advances in Agricultural Science \& Technology, Vol.8 Issue.10, October-2021, pg. 29-38

ISSN: $2348-1358$ Impact Factor: 6.057

NAAS Rating: 3.77

The calculated coefficient of co-relation between knowledge and adoption level of respondents towards improved production practices of cotton and their social economic profile revealed the following results which clearly indicates that selected independent variables i.e. age, education, annual income, land holding, mass media exposure, extension contacts, source of information, innovativeness, progressiveness, risk orientation had positive and highly significant relationship at $0.01 \%$ level of probability with dependent variables i.e. knowledge level of farmers towards improved production practices of cotton. These findings are similar with Umesh (2009) and Jeya (2020).

\section{CONCLUSION}

It was concluded that majority of the farmers belonged to the middle age group followed by low level of education, medium level in of land holding, medium level of annual income followed by low level of extension contact \& mass media exposure. It was evident that medium level of knowledge of farmers towards improved production practices of cotton. The association shown that the independent variables i.e. Age, education, annual income, land holding, mass media exposure, extension contacts, source of information, innovativeness, progressiveness, risk orientation with the dependent variables knowledge had positive and significant relationship.

\section{REFERENCES}

[1]. Jadav, N.B., Undhad, S.V., Sharma, P.S. (2018). Growers Knowledge and Adoption of Chemical Fertilizer in Bt. Cotton in Gujarat. J Krishi Vigyan, 7 (Special Issue) : 69-73.

[2]. Jeya, R. (2020). Knowledge level of hybrid cotton growers on cotton cultivation practices, Plant Archives 20(1), pp. 503-505.

[3]. Kalidasan, T., Loganathan, B., Natrajan, M., Kavaskar, M and Muruganandam, C. (2020). Adoption level of improved agricultural technologies among the cotton growers of perambalur district, Plant Archives 20 (1), pp. 1377-1381.

[4]. Padwal, D., Jahanara., Bose, D.K., Mazhar. S.H., Srivastava, JP. (2018). A study on knowledge of BT cotton cultivation practices in Rangareddy district of Telangana, Journal of Pharmacognosy and $P$ Phytochemistry ;7(3): 2204-2205.

[5]. Patel and Sanwal (2015) concluded that 67.50 percent respondents had medium level followed by 17.50 percent respondents fall under the low level of knowledge and 15.00 percent of high level regarding IPM strategy in hybrid cotton crop. 


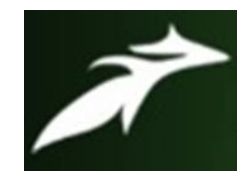

Kamishetty Uday Kumar et al, International Journal of Advances in Agricultural Science \& Technology, Vol.8 Issue.10, October-2021, pg. 29-38

ISSN: 2348-1358

Impact Factor: 6.057

NAAS Rating: 3.77

[6]. Pavan, K.P. and Dhorey, R.K. (2017). Extent of Adoption of Farmers about Bt Cotton Practices in Warangal District of Telangana State, India, Int.J.Curr.Microbiol.App.Sci 6(11): 824-829.

[7]. Rajeshwar, S.J., Patange, N.R and Kadam, S.B. (2019). Extent of Adoption of Practices by Cotton Growers for the Management of Pink Boll Worm, Trends in Biosciences 12 (3), 246-250.

[8]. Umesh, R. (2009). Factors Influencing Adoption of Cotton Cultivation Practices in the Rehabilitated Areas, Mysore J. Agricultural Sciences.43 (4) : 757-762. 